\title{
AVALIAÇÃO DO EFEITO DE VARIÁVEIS METEOROLÓGICAS NA GUALIDADE INDUSTRIAL E NO RENDIMENTO DE GRÃOS DE TRIGO PELO EMPREGO DE ANÁLISE DE COMPONENTES PRINCIPAIS ${ }^{1}$
}

\author{
Eliana Maria GUARIENTI ${ }^{2, *}$, César Francisco CIACCO ${ }^{3}$, Gilberto Rocca da CUNHA ${ }^{2}$, Leo de Jesus
}

\author{
Antunes DEL DUCA ${ }^{2}$, Celina Maria de Oliveira CAMARGO ${ }^{4}$
}

\section{RESUMO}

A qualidade industrial de trigo, além de ser afetada pelo genótipo, também é influenciada por fatores ambientes, como as condições meteorológicas prevalecentes durante a permanência da cultura na lavoura. Este trabalho teve por objetivo verificar a influência de variáveis meteorológicas, bem como do déficit e do excesso hídrico do solo, no peso do hectolitro (PH), no peso de mil grãos (PMG), na extração experimental de farinha (EXT), na força geral de glúten (W), na relação P/L (P/L), na microssedimentação com dodecil sulfato de sódio (SDS) e no número de queda (NQ). Foram usados dados de experimentos com trigo EMBRAPA 16, conduzidos nos anos de 1990 a 1998, em sete locais do Rio Grande do Sul e em quatro locais de Santa Catarina. A análise estatística realizada foi de componentes principais. Verificou-se que: a) a precipitação pluvial, a umidade relativa do ar e o excesso hídrico do solo influenciaram negativamente o PH, o PMG, o NQ, a P/L e o rendimento de grãos. O W, a EXT e a SDS foram afetados positiva e negativamente por essas variáveis, dependendo do período de avaliação estudado; b) a temperatura mínima influenciou positivamente a EXT, o W e a SDS. Para as demais variáveis, quando ocorreu influência da temperatura minima, esta foi negativa; c) a temperatura média associou-se negativamente com o PH, com o PMG, com o NQ e com o rendimento de grãos e positivamente com a EXT e com o W. Para a P/L e para a SDS, a temperatura média afetou tanto positiva quanto negativamente; d) a temperatura máxima correlacionou-se negativamente com o rendimento de grãos e positivamente com a EXT. O W, a SDS e a P/L apresentaram períodos de correlação positivos e negativos com a temperatura máxima; e e) a radiação solar global influenciou positivamente todas as características estudadas, exceto a SDS.

Palavras-chave: precipitação pluvial; temperatura; radiação solar global; força geral de glúten; sedimentação; número de queda; trigo; qualidade.
\end{abstract}

\section{SUMMARY}

EVALUATION OF THE EFFECT OF CLIMATE VARIABLES ON INDUSTRIAL WHEAT QUALITY AND ON GRAIN YIELD USING PRINCIPAL COMPONENT ANALYSIS. Wheat baking quality, besides being affected by genotype, is also influenced by environmental factors, such as climate conditions during crop development in the field. This work aimed to verify the influence of climate variables and soil water deficit and excess on the following quality parameters: test weight (TW), 1,000 kernel weight (KW), experimental milling of flour (MIL), gluten strength (W), P/L relation (P/L), dodecyl sulphate microssedimentation test (SDS), and falling number (FN). Data obtained with EMBRAPA 16 wheat, in the 1990-1998 period in seven locations from Rio Grande do Sul State and four locations from Santa Catarina State were used. The statistical analysis used was the analysis of principal components. It was verified that: a) the sum of rainfall, the relative humidity of the air and the water excess influenced negatively TW, KW, FN, P/L and the grain yield. W, MIL, and SDS were both positively and negatively affect by these variables, depending on the period studied; b) minimum temperature influenced positively W, MIL, and SDS. For the other variables, when there was influence of minimum temperature, it was negative; c) the average temperature was negatively associated with TW, KW, FN, and grain yield, and positively with MIL and W. For P/L and SDS, the average temperature affected was either positive or negative; d) the maximum temperature was negatively correlated with grain yield and positively with MIL, $\mathrm{W}, \mathrm{SDS}$, and P/L presented positive and negative correlation periods with the maximum temperature; and e) the global solar radiation influenced positively all the studied characteristics, except for SDS.

Keywords: rainfall; temperature; global solar radiation; gluten strength; sedimentation; falling number; wheat; quality.

\section{1 - INTRODUÇÃO}

Cerca de $90 \%$ da produção de trigo no Brasil está localizada nos Estados do Paraná, do Rio Grande do Sul e de Santa Catarina. Nesses Estados, a variabilidade climática é muito grande, de tal forma que a produção tritícola torna-se uma atividade de risco.

Os principais problemas climáticos da triticultura, nesses Estados são excesso de umidade relativa do ar

${ }^{1}$ Recebido para publicação em 17/09/2002. Aceito para publicação em 26/02/2003 (000975).

2 EMBRAPA-Centro Nacional de Pesquisas de Trigo (CNPT), caixa postal 451, CEP 99001-970,Passo Fundo-R.S.E-mail: eliana@cnpt.embrapa.br, cunha@cnpt.embrapa.br

${ }^{3}$ Departamento de Tecnologia de Alimentos - Faculdade de Engenharia de Alimentos - UNICAMP, caixa postal 6121, Campinas-SP. E-mail: ciacco@obelix.unicamp.br

${ }^{4}$ Departamento de Tecnologia de Alimentos - Faculdade de Engenharia de Alimentos - UNICAMP

* A quem a correspondência deve ser enviada. (em setembro-outubro), ocorrência de geadas no espigamento, chuvas na colheita e granizo [50].

No Brasil, instituições de pesquisa de trigo têm promovido trabalhos para verificar a multiplicidade de fatores climáticos que afetam a produção e a produtividade de trigo [17]. Entre as investigações mais importantes, cita-se o zoneamento de riscos climáticos para a cultura de trigo no Rio Grande do Sul, desenvolvido pela EMBRAPA - Empresa Brasileira de Pesquisa Agropecuária, através do Centro Nacional de Pesquisa de Trigo [18], pela EPAGRI - Empresa de Pesquisa Agropecuária e Extensão Rural de Santa Catarina S.A. [75], em Santa Catarina, e, no Paraná, pelo IAPAR - Instituto Agronômico do Paraná e pelo Centro Nacional de Pesquisa de Soja da EMBRAPA [33].

O estabelecimento de regiões de plantio com caracteristicas semelhantes, para as quais são recomendadas tecnologias de produção específicas a cada situação, teve como objetivo principal a otimização da produção e da produtividade e, como objetivo secundário, manutenção 
da qualidade industrial de trigo. No entanto, em nenhum momento foi considerada a influência de cada variável meteorológica na qualidade industrial de trigo.

A qualidade industrial de trigo pode ser definida mediante vários testes físico-químicos (peso do hectolitro, peso de mil grãos, extração experimental de farinha, número de queda, microssedimentação com dodecil sulfato de sódio, etc.) e reológicos (alveografia, farinografia, etc.).

Muitos investigadores estudaram a influência da precipitação pluvial ou da umidade relativa [38, 43, 49], de elevada temperatura $[9,14,67,68,70]$, da combinação de elevada temperatura e precipitação ou umidade relativa [36, 42, 64] e de baixa temperatura [27, 55], na qualidade industrial de trigo.

O conhecimento dos riscos de natureza climática que interferem na qualidade industrial de trigo produzido no Sul do Brasil pode amenizar o risco de perdas econômicas, além de contribuir para oferta de matérias-primas adequadas às necessidades das indústrias brasileiras. Além disso, o conhecimento dos períodos críticos em que as variáveis meteorológicas podem afetar a qualidade industrial de trigo possibilita adoção de práticas de manejo que visam à otimização do cultivo de trigo e à melhoria da qualidade dessa matéria-prima.

O presente trabalho teve por objetivo verificar quais são as principais variáveis meteorológicas que afetam a qualidade industrial e o rendimento de grãos de trigo, nas condições da Região tritícola Sul-Brasileira.

\section{2 - MATERIAL E MÉTODOS}

Foram usadas amostras de experimentos com a cultura de trigo, conduzidos por órgãos oficiais de pesquisa, realizados no Rio Grande do Sul e em Santa Catarina, durante os anos de 1990 a 1998, no âmbito do projeto "Melhoramento Genético de Trigo para o Brasil", liderado pela EMBRAPA - Centro Nacional de Pesquisa de Trigo. Essas informações são apresentadas na Tabela 1.

TABELA 1. Região tritícola, local, ano de plantio e ensaio em que foram produzidas as amostras de trigo EMBRAPA 16.

\begin{tabular}{|c|c|c|c|c|c|c|c|c|c|c|}
\hline \multirow{2}{*}{$\begin{array}{l}\text { Região } \\
\text { tritícola }\end{array}$} & \multirow{2}{*}{$\begin{array}{l}\text { Local de } \\
\text { plantio }\end{array}$} & \multicolumn{9}{|c|}{ Ano de plantio } \\
\hline & & 1990 & 1991 & 1992 & 1993 & 1994 & 1995 & 1996 & 1997 & 1998 \\
\hline I & Vacaria & - & ESB & EEC & EPRII & ER & ESB & ESB & EEC & - \\
\hline II & $\begin{array}{l}\text { Lagoa } \\
\text { Vermelha }\end{array}$ & - & - & - & - & ESB & ESB & ESB & EEC & EEC \\
\hline III & $\begin{array}{l}\text { Passo } \\
\text { Fundo }\end{array}$ & ESB & ESB & EEC & EEC & EEC & ESB & ESB & EEC & EEC \\
\hline IV & $\begin{array}{l}\text { Santo } \\
\text { Ângelo }\end{array}$ & - & ESB & - & EEC & EEC & ESB & ESB & - & - \\
\hline V & São Borja & - & - & - & - & ESB & ESB & - & - & - \\
\hline VII & Pelotas & - & ESB & - & - & - & ESB & ER & - & EEC \\
\hline VIII & Piratini & - & ESB & - & - & EEC & ESB & ER & - & EEC \\
\hline $3 \mathrm{~A}$ & $\begin{array}{l}\text { Campos } \\
\text { Novos }\end{array}$ & - & ESB & - & EEC & EEC & ESB & ESB & EEC & - \\
\hline 3B & Canoinhas & - & - & - & EEC & - & ESB & - & - & - \\
\hline $3 \mathrm{C}$ & $\begin{array}{l}\text { Abelardo } \\
\text { Luz }\end{array}$ & - & ESB & - & EEC & EEC & ESB & ESB & - & - \\
\hline $3 C$ & Chapecó & - & - & - & EEC & - & ESB & ESB & EEC & EEC \\
\hline
\end{tabular}

A cultivar usada foi EMBRAPA 16, resultante do cruzamento duplo Hulha Negra/CNT 7//Amigo/CNT 7, re- comendada pela EMBRAPA Trigo em 1992 [26] e classificada comercialmente como Trigo Pão.

As amostras analisadas compunham os ensaios Preliminar em Rede, Sul-Brasileiro de Trigo, Regional de Linhagens de Trigo e Estadual de Cultivares de Trigo, conduzidos segundo delineamento experimental de blocos ao acaso com quatro repetições. A densidade de semeadura usada foi de 300 a 330 sementes viáveis $/ \mathrm{m}^{2}$. A área de cada parcela foi de cinco metros quadrados (cinco fileiras de plantas de cinco metros de comprimento, espaçadas vinte centímetros), sendo a área útil de três metros quadrados (três fileiras de plantas centrais).

A correção e a fertilização do solo, em cada local, foram realizadas conforme as recomendações da SOCIEDADE BRASILEIRA DE CIÊNCIA DO SOLO [65], para expectativa de produtividade superior a $2.000 \mathrm{Kg} / \mathrm{ha}$. A fertilização com nitrogênio em cobertura foi realizada aos 30 a 45 dias após a emergência, em todos os experimentos.

A colheita, nos diferentes locais, foi realizada manualmente ou com colhedora de parcelas.

As quatro repetições de cada uma das amostras de grãos foram misturadas constituindo, dessa forma, amostras compostas, que foram encaminhadas ao Laboratório de Qualidade Industrial de Trigo, da EMBRAPA Trigo, para a realização das seguintes análises de qualidade:

a) peso do hectolitro - medido por aparelho Dalle Molle, segundo método descrito pelo fabricante [4]. Nessa análise, os resultados foram padronizados para $13 \%$ de umidade, mediante cálculo de perda/ganho de umidade [56];

b) peso de mil grãos - usou-se o método descrito por BRASIL [12];

c) extração experimental de farinha - usou-se moinho experimental Quadrumat Sênior, da marca Brabender, segundo método AACC no 26-94 [1];

d) alveografia - adotou-se o método de análise da AACC no 54/30 [1]. Consideraram-se apenas os valores de força geral de glúten (W) e da relação entre tenacidade e extensibilidade (relação $\mathrm{P} / \mathrm{L}$ );

e) número de queda - empregou-se método descrito pela AACC no 54-81 B [1]; e

f) teste de microssedimentação com dodecil sulfato de sódio - usou-se método baseado em AXFORD et al. [3], apenas modificando-se as proporções das amostras e dos reagentes para testar dois gramas de farinha.

As observações meteorológicas foram provenientes de onze Estações do Instituto Nacional de Meteorologia/8o Distrito de Meteorologia (INMET/8ㅇ DISME), da FEPAGRO (Fundação Estadual de Pesquisa Agropecuária), no Rio Grande do Sul, e da EPAGRI (Empresa de Pesquisa Agropecuária e Extensão Rural de Santa Catarina S.A).

Os municipios de Piratini e de Santo Ângelo, no Rio Grande do Sul e, de Canoinhas, em Santa Catari- 
na, não possuem estações meteorológicas, portanto, foram usados registros de estações meteorológicas de municípios vizinhos, pertencentes à mesma Região tritícola, ou seja, respectivamente, Encruzilhada do Sul, Santa Rosa e Major Vieira.

Empregaram-se observações meteorológicas diárias dos oitenta dias anteriores à colheita dos diferentes ensaios de trigo.

As variáveis meteorológicas analisadas foram:

a) precipitação pluvial ( $\mathrm{mm}$ ) - Foi usado o pluviômetro tipo "Ville de Paris" ou o pluviógrafo tipo Hellmann, localizado a $1,5 \mathrm{~m}$ sobre o nivel do solo;

b) radiação solar global $\left(\mathrm{MJ} / \mathrm{m}^{2}\right.$ dia) - usou-se o Actinógrafo tipo Robitzsch-Fuess, localizado a 1,5m sobre o nivel do solo;

c) temperatura $\left({ }^{\circ} \mathrm{C}\right)$ - empregaram-se termômetros, 1ocalizados no abrigo meteorológico padrão a $1,5 \mathrm{~m}$ sobre o nivel do solo;

d) umidade relativa do ar (\%) - usou-se psicrômetro, localizado no abrigo meteorológico padrão a $1,5 \mathrm{~m}$ sobre o nivel do solo.

Foi usado o método de cálculo de balanço hídrico desenvolvido por THORNTHWAITE \& MATHER [76], que consiste no cotejo entre a precipitação pluvial e a temperatura média, considerando-se 75 milimetros a capacidade de armazenamento de água no solo. Os cálculos do balanço hídrico climático foram realizados por meio de planilhas em ambiente Excel ${ }^{\mathrm{TM}}$, desenvolvidas por ROLIM et al. [61]. Os valores empregados nesse trabalho foram o déficit e o excesso hídrico do solo.

Para fins de comparação entre variáveis meteorológicas (regressoras) e variáveis rendimento de grãos e qualidade de trigo (resposta), foi criado arquivo que incluiu dados dos somatórios de precipitação e de radiação solar global, bem como das médias da temperatura máxima, mínima e média e da umidade relativa do ar, divididos em oito periodos de dez em dez dias - de um a dez, onze a vinte, vinte e um a trinta, trinta e um a quarenta, quarenta e um a cinqüenta, cinqüenta e um a sessenta, sessenta e um a setenta e setenta e um a oitenta dias anteriores à colheita;

Foi realizada a análise multivariada de componentes principais, na qual o processo de análise fatorial foi usado para decompor a matriz de dados em duas matrizes menores, com o objetivo de simplificar (compactar) a representação do conjunto de dados [29].

A análise de componentes principais foi realizada considerando as variáveis de qualidade industrial (peso do hectolitro, peso de mil grãos, extração experimental de farinha, força geral de glúten, relação $\mathrm{P} / \mathrm{L}$, número de queda, microssedimentação com dodecil sulfato de sódio) e rendimento de grãos de trigo e as variáveis meteorológicas (somatório da precipitação pluvial, médias da temperatura máxima, minima e média, média da umidade relativa do ar, somatório da radiação solar global, déficit hídrico do solo e excesso hídrico do solo).

\section{3 - RESULTADOS E DISCUSSÃO}

Os valores de rendimento de grãos usados neste trabalho foram publicados, originalmente, nos seguintes trabalhos:

a) Ensaios Estaduais de Cultivares de Trigo, conduzidos no Rio Grande do Sul em 1992, 1997 e 1998 [84,85,86]; em 1993 [79] e, em 1994 [78];

b) Ensaios Regionais de Linhagens de Trigo, conduzidos no Rio Grande do Sul em 1994 e 1996 [73, 74];

c) Ensaios Sul-Brasileiros de Trigo, conduzidos no Rio Grande do Sul em 1990, 1991, 1994, 1995 e 1996 [44, 45, 46, 47, 48];

d) Ensaios Sul-Brasileiros de Trigo e Estaduais de Cultivares de Trigo, conduzidos em Santa Catarina em 1991, 1993, 1994, 1995, 1996, 1997 e, em 1998 [19, 20, 21, 22, 23, 24, 25].

$\mathrm{Na}$ Tabela 2 são apresentados a média, os valores máximo e mínimo e o desvio padrão das variáveis de qualidade industrial e rendimento de grãos, do trigo EMBRAPA 16, plantado em diferentes anos e locais.

TABELA 2. Média, valores máximo e mínimo e desvio padrão das variáveis de qualidade industrial e rendimento de grãos, do trigo EMBRAPA 16, plantado em diferentes anos e locais.

\begin{tabular}{lcccc}
\hline $\begin{array}{l}\text { Variável de qualidade industrial e } \\
\text { rendimento de grãos }\end{array}$ & Média & $\begin{array}{c}\text { Valor } \\
\text { máximo }\end{array}$ & $\begin{array}{c}\text { Valor } \\
\text { mínimo }\end{array}$ & $\begin{array}{c}\text { Desvio } \\
\text { padrão }\end{array}$ \\
\hline Peso do hectolitro (kg/hL) & 75,8 & 82,0 & 59,8 & 4,2 \\
Peso de mil grãos (gramas) & 30,8 & 39,2 & 21,2 & 4,5 \\
Extração experimental de farinha (\%, base & 60,1 & 69,1 & 49,5 & 4,8 \\
14\% de umidade) & & & & \\
Força geral de glúten (10 $\left.{ }^{-4} \mathrm{~J}\right)$ & 223 & 348 & 69 & 61 \\
Relação P/L (mm) & 0,80 & 2,49 & 0,33 & 0,42 \\
Número de queda (segundos) & 341 & 458 & 182 & 76 \\
Sedimentação MS-SDS (mL) & 14,3 & 21,0 & 7,0 & 2,9 \\
Rendimento de grãos (kg/ha) & 2911 & 6433 & 1246 & 1037 \\
\hline
\end{tabular}

Nas Figuras 1 a 8 estão as representações dos componentes principais, mostrando o efeito das variáveis meteorológicas sobre características de qualidade industrial e rendimento de grãos de trigo EMBRAPA 16.

Nos períodos estudados, os fatores 1 e 2, da análise de componentes principais, explicaram, juntos, de 37,97 a $47,91 \%$ da variabilidade dos dados.

Conforme observado nas Figuras 1 a 8, a maior parte dos períodos estudados apresentou duas a três variáveis meteorológicas, afetando simultaneamente as características de qualidade e rendimento de grãos de trigo.

A porcentagem de períodos que o somatório da precipitação pluvial associou-se negativamente com peso do hectolitro, peso de mil grãos e número de queda foi de 62,5\%; com a relação $\mathrm{P} / \mathrm{L}$, foi de $75 \%$; e com rendimento de grãos, de $50 \%$. A força geral de glúten e a extração experimental de farinha apresentaram 12,5\% dos periodos com correlações positivas e $50 \%$ dos periodos com correlações negativas. 

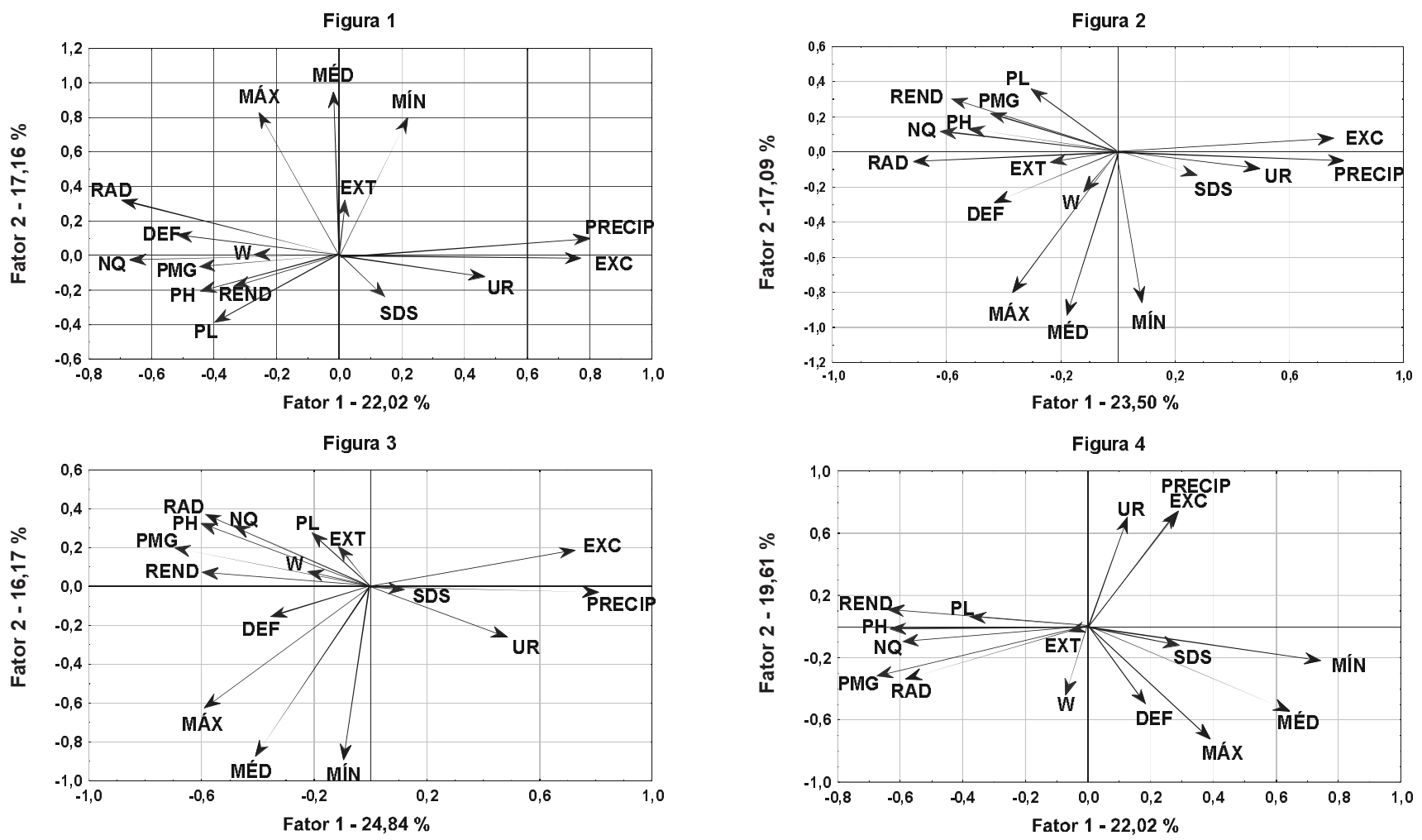

Figura 5
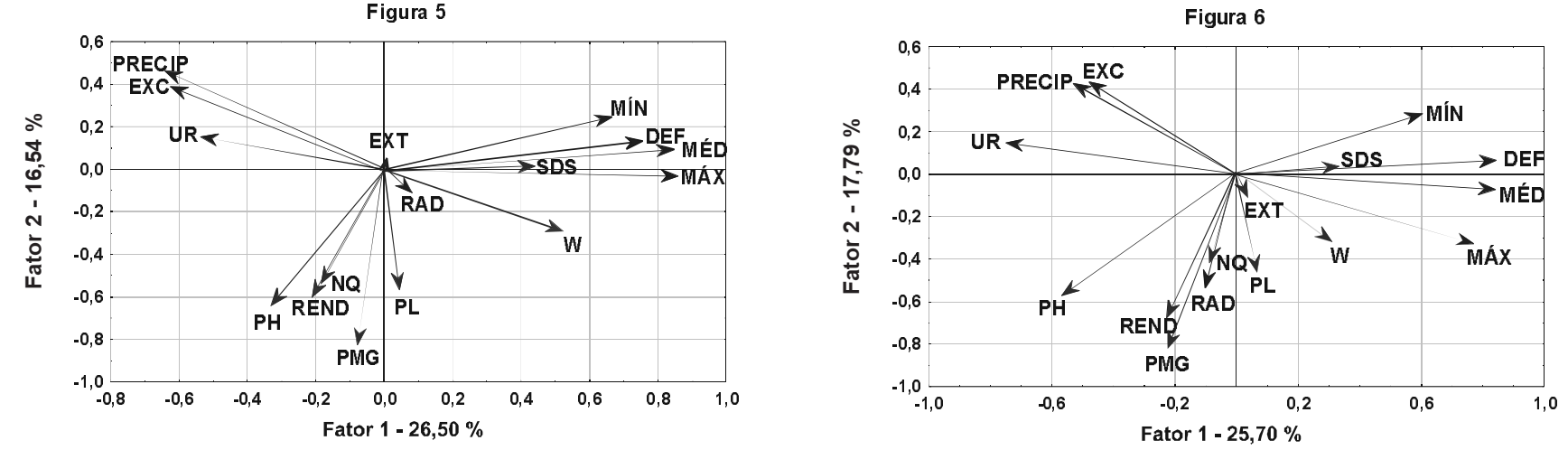

Figura 7
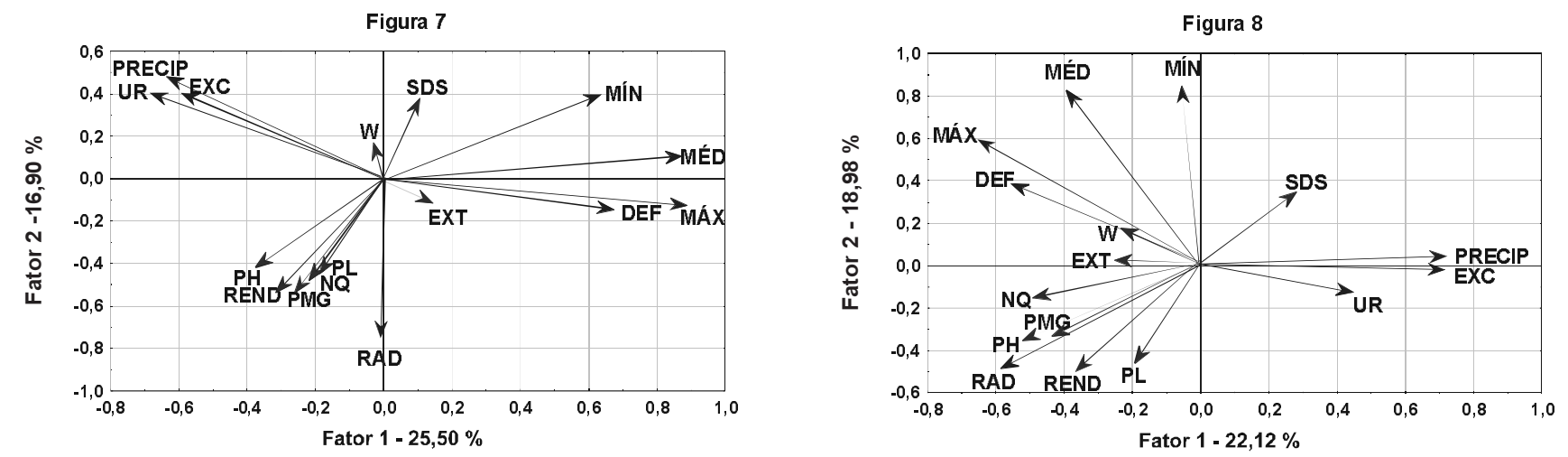

(MIN, MÉD e MÁX = médias da temperatura minima, média e máxima, respectivamente; UR = média da umidade relativa do ar; RAD = somatório da radiação solar global; e PRECIP = somatório da precipitação pluvial) sobre características de qualidade industrial ( $\mathrm{PH}=$ peso do hectolitro; PMG = peso de mil grãos; EXT = extração experimental de farinha; $\mathrm{W}$ = força geral de glúten; $\mathrm{P} / \mathrm{L}$ = relação entre a tenacidade e a extensibilidade; NQ = número de queda; $\mathrm{SDS}$ = microssedimentação com dodecil sulfato de sódio); e rendimento de grãos de trigo EMBRAPA 16 = REND.

FIGURAS 1 A 8. Análise de componentes principais mostrando o efeito das variáveis meteorológicas obtidas no período de um a dez (Figura 1), onze a vinte (Figura 2), vinte e um a trinta (Figura 3), trinta e um a quarenta (Figura 4), quarenta e um a cinqüenta (Figura 5), cinqüenta e um a sessenta (Figura 6), sessenta e um a setenta (Figura 7), setenta e um a oitenta (Figura 8) dias anteriores à colheita 
O somatório da precipitação pluvial apresentou $100 \%$ de correlação nula com microssedimentação com dodecil sulfato de sódio (Figuras 1 a 8).

O excesso hídrico do solo associou-se, negativamente, em $12,5 \%$ dos periodos, com peso do hectolitro, peso de mil grãos e número de queda; em 25,0\% dos períodos com a relação $\mathrm{P} / \mathrm{L}$ e, em $62,5 \%$ dos períodos, com extração experimental de farinha. Para microssedimentação com dodecil sulfato de sódio, a influência do excesso hídrico do solo foi positiva em $12,5 \%$ dos períodos. A força geral de glúten apresentou $12,5 \%$ dos períodos com correlações positivas e $75,0 \%$ dos períodos com correlações negativas (Figuras 1 a 8).

De acordo com dados das Figuras 1 a 8, a porcentagem de períodos em que a média da umidade relativa do ar associou-se negativamente com peso do hectolitro, peso de mil grãos e número de queda foi de $37,5 \%$, com a relação $\mathrm{P} / \mathrm{L}$ foi de $50,0 \%$, com rendimento de grãos foi de $25 \%$ e com extração experimental de farinha, foi de $62,5 \%$. Para microssedimentação com dodecil sulfato de sódio, a influência da média da umidade relativa do ar foi positiva em $37,5 \%$ dos períodos. A força geral de glúten apresentou períodos com correlações positivas $(12,5 \%)$ e periodos com correlações negativas $(75,0 \%)$.

A porcentagem de periodos que o déficit hídrico do solo associou-se negativamente com peso do hectolitro, peso de mil grãos e número de queda foi de $25,0 \%$, com relação $\mathrm{P} / \mathrm{L}$, de 12,5\% e com rendimento de grãos, de $37,5 \%$. Para a extração experimental de farinha, a influência do déficit hídrico do solo foi positiva em 50,0\% dos períodos. A força geral de glúten e a microssedimentação com dodecil sulfato de sódio apresentaram 37,5\% dos períodos com correlações positivas e $12,5 \%$ dos períodos com correlações negativas (Figuras 1 a 8).

A influência do somatório de precipitação pluvial, média da umidade relativa do ar, déficit e excesso hídrico no solo no peso do hectolitro, no peso de mil grãos e no rendimento de grãos pode ser explicada por diferentes mecanismos conforme os períodos em que a planta se encontra (enchimento de grãos ou após a maturação fisiológica).

Neste trabalho, no período estimado de enchimento de grãos, ou seja, no periodo compreendido entre sessenta e dez dias antes da colheita, os resultados parecem indicar a influência dessas variáveis meteorológicas no peso do hectolitro, no peso de mil grãos e no rendimento de grãos. Isso pode ser explicado pelo mecanismo que mostra a interferência dessas variáveis meteorológicas na sintese de produtos fotossintéticos que promovem enchimento dos grãos, segundo descrito por BERGAMASCHI [5], por DUBETZ \& BOLE [28] e por REICHARDT [59].

HIRANO [38] mostrou que o mecanismo da deterioração da qualidade industrial de trigo decorrente de chuva ocorrida em periodos de mais de 20 dias antes da colheita foi devido ao decréscimo do enchimento de grãos, resultante da redução na acumulação da matéria seca causada por redução da fotossintese e absorção de nutrientes. Os grãos começaram a ficar chochos, e o peso do hectolitro e o peso de mil grãos decresceram. Confir- mando dados encontrados por esse autor, alguns resultados obtidos neste trabalho também comprovam a influência negativa da precipitação pluvial no peso do hectolitro e no peso de mil grãos, observada em períodos de mais de vinte dias anteriores à colheita.

Por outro lado, MELLADO et al. [43] concluiram que a diminuição do peso do hectolitro pode ser atribuída a mudanças sucessivas na umidade do grão, produto das aplicações de água. Da mesma forma, FINNEY \& YAMAZAKI [30] assinalaram que o umidecimento e a secagem do grão de trigo reduzem o peso do hectolitro, como conseqüência da diminuição da densidade. Essas deduções também podem explicar os resultados encontrados nesse trabalho.

Com relação ao rendimento de grãos, pode-se especular que os resultados obtidos são devidos ao estresse por água, que provoca a modificação de estruturas vegetativas da planta, como área foliar, a qual determina a capacidade fotossintética [28], ou, então, à redução do número de grãos desenvolvidos [15].

No entanto, após o período de maturação físiológica da planta, aproximadamente dez dias anteriores à colheita, a redução do peso do hectolitro, do peso de mil grãos e do rendimento de grãos pode ser devida à germinação pré-colheita [2, 6].

Nos casos de grãos que germinam antes da colheita, a diminuição do rendimento de grãos, do peso de mil grãos e do peso do hectolitro deve-se à elevada taxa de respiração, a qual consome carboidratos acumulados nos grãos [6]. Esta teoria pode explicar os resultados obtidos neste trabalho.

A ocorrência de correlações negativas entre extração experimental de farinha e umidade relativa do ar e excesso hídrico do solo poderia ser atribuída à influência dessas variáveis meteorológicas no enchimento de grãos, conforme descrito acima, afetando peso do hectolitro, peso de mil grãos e, conseqüentemente, as caracteristicas de moagem dos grãos.

Os resultados obtidos no presente trabalho, relativos à influência do somatório da precipitação pluvial e das médias da umidade relativa do ar, do déficit e do excesso hídrico do solo na força geral de glúten, na relação $\mathrm{P} / \mathrm{L}$ e na microssedimentação com dodecil sulfato de sódio, provavelmente são, em parte, devidos à influência das variáveis meteorológicas em consideração no teor e na qualidade de proteínas dos grãos de trigo.

A força da farinha (analisada pela força geral de glúten e pela microssedimentação com dodecil sulfato de sódio) são características de qualidade altamente afetadas pela qualidade e quantidade de proteínas presentes nos grãos [63]. Nesse mesmo raciocínio, de acordo com MANDARINO [41], a extensibilidade e a tenacidade ou elasticidade (medidas na relação P/L) são afetadas pelo teor das proteinas gliadinas e gluteninas, que, juntamente com o resíduo protéico, fazem parte do glúten, um dos conjuntos de proteinas presentes nos grãos de trigo [37].

Da mesma forma que para força geral de glúten, o valor de microssedimentação com dodecil sulfato de sódio 
também pode estar sendo afetado pelo conteúdo de proteínas dos grãos. Dessa forma, os resultados obtidos referentes à correlação positiva entre essas características de qualidade e o déficit hídrico do solo estão em concordância com as informações de READ \& WARDER [58]. Esses autores verificaram que a disponibilidade de água no solo foi negativamente correlacionada com o conteúdo de proteinas. O decréscimo do teor de proteínas, quando associado ao incremento da quantidade de água disponivel no solo, é devido à profundidade do armazenamento da água no solo, à localização de $\mathrm{NO}_{3}-\mathrm{N}$ no perfil do solo e ao padrão de uso da água. Estes fatores influenciam a absorção de $\mathrm{NO}_{3}-\mathrm{N}$, fonte de nitrogênio usada na formação de proteinas das plantas.

Neste trabalho, observou-se redução do número de queda, com o aumento da precipitação pluvial, do excesso hídrico do solo e da umidade relativa do ar, em vários periodos que antecedem à colheita, conforme citado anteriormente. Esses resultados estão em concordância com CORNFORD et al. [16] e com NODA et al. [52], os quais, citaram que, associando-se a embebição de água e a baixa temperatura, tem-se, como conseqüência, a quebra de dormência dos grãos e ativação da sintese da alfa-amilase, que provoca a diminuição do número de queda.

A temperatura máxima média não apresentou correlação com peso do hectolitro, peso de mil grãos e número de queda. Com as demais características de qualidade industrial e rendimento de grãos, o percentual de correlação nula variou de 25,0 a $87,5 \%$ dos períodos estudados. Porém, o percentual de periodos que a temperatura máxima média associou-se negativamente com rendimento de grãos foi de $12,5 \%$, e positivamente, com extração experimental de farinha, foi de 50,0\%. A força geral de glúten, relação $\mathrm{P} / \mathrm{L}$ e microssedimentação com dodecil sulfato de sódio apresentaram periodos com correlações positivas $(62,5 \%, 25,0 \%$ e $12,5 \%$, respectivamente) e períodos com correlações negativas $(12,5 \%)$;

Em concordância com os resultados obtidos neste trabalho, informações de literatura mostram que a influência de elevada temperatura afeta negativamente o rendimento de grãos $[7,13,32,60,70,71,80,81]$.

Correlações positivas entre temperatura, durante os estádios iniciais de enchimento de grãos, e conteúdo de proteinas foram encontradas por vários autores $[9,39$, 40, 57, 62, 66, 67, 77].

Conforme obtido neste trabalho, em relação à força geral de glúten e à microssedimentação com dodecil sulfato de sódio, dados de literatura indicaram que a incidência de elevada temperatura (acima de $30^{\circ} \mathrm{C}$ ) pode afetar negativamente a força de glúten [10, 11, 14, 31, 36].

Por outro lado, a temperatura máxima média influenciou positivamente a microssedimentação com dodecil sulfato de sódio. Esse resultado está em concordância com os obtidos por UHLEN et al. [77], em que, com a elevação da temperatura, aumentou a microssedimentação com dodecil sulfato de sódio. Segundo esses autores, a causa do maior valor dessa característica foi o incremento da proporção de proteinas poliméricas.
O percentual de periodos em que a temperatura mínima média associou-se negativamente com peso do hectolitro, peso de mil grãos e número de queda foi de $62,5 \%$, com a relação $\mathrm{P} / \mathrm{L}$, de $50,0 \%$, com o rendimento de grãos, de $75 \%$. Para extração experimental de farinha, para força geral de glúten e para microssedimentação com dodecil sulfato de sódio, a influência da temperatura mínima média foi positiva em $37,5 \%, 12,5 \%$ e $62,5 \%$ dos períodos estudados, respectivamente (Figuras 1 a 8$)$.

A temperatura minima média influenciou negativamente o peso do hectolitro, peso de mil grãos e rendimento de grãos. Esse fato pode ser explicado por GRAYBOSCH \& MORRIS [35], os quais relataram que a temperatura ideal para desenvolvimento de trigo situase entre 12 e $15^{\circ} \mathrm{C}$, durante o desenvolvimento de grãos, e que temperatura superior a $15^{\circ} \mathrm{C}$ provoca decréscimo de 3 a $5 \%$ no peso do hectolitro, com conseqüência no peso de mil grãos e no rendimento de grãos. Pode-se supor que temperatura mais elevada (incluindo-se a minima superior a $15^{\circ} \mathrm{C}$ ) obtida neste trabalho afetou negativamente essas características. Na Tabela 3, verificou-se que os maiores valores de temperatura minima variaram de 16,3 a $23,4^{\circ} \mathrm{C}$. Cabe salientar que a redução no rendimento de grãos ocasionada pela temperatura elevada resulta do efeito da temperatura na redução do período de enchimento de grãos, que não é compensado por um aumento na taxa de crescimento dos grãos [67, 69].

As correlações positivas entre força geral de glúten e microssedimentação com dodecil sulfato de sódio com a temperatura minima média não estão de acordo com os resultados obtidos por STONE et al. [67] e por POPINEAU et al. [53], que mostram que baixa temperatura durante o desenvolvimento de trigo ou, mais especificamente, quando o grão estiver imaturo, afeta negativamente a qualidade e a quantidade de glúten e, conseqüentemente, a força geral de glúten e a microssedimentação com dodecil sulfato de sódio. Esse fenômeno é devido a maior deposição de amido comparativamente às proteínas, quando a temperatura é baixa, de forma a propiciar menor teor de proteínas nos grãos [60] e, por extensão, menor teor de glúten.

Pode-se conjeturar que a correlação negativa entre relação $\mathrm{P} / \mathrm{L}$ e temperatura mínima média é devida à deposição diferencial das proteinas durante o período de enchimento de grãos [70]. O aumento da relação P/L, com conseqüente acréscimo da elasticidade do glúten, pode ser provocado pela elevação do teor de gluteninas. Essas proteinas apresentam elevada elasticidade e baixa extensibilidade [41]. Por outro lado, a redução da relação $\mathrm{P} / \mathrm{L}$ pode ser explicada pelo aumento do teor de gliadinas, que são responsáveis por baixa elasticidade e elevada extensibilidade do glúten [41].

A correlação negativa entre temperatura minima média e número de queda, está em contradição com vários autores, que verificaram que, em campo, a germinação pré-colheita é induzida quando grãos absorvem água em baixa temperatura e também que a embebição de água 
em baixa temperatura promove quebra de dormência e resulta na germinação pré-colheita $[8,16]$.

TABELA 3. Número de amostras, média, valores mínimo e máximo e desvio padrão das variáveis meteorológicas, somatório da precipitação pluvial (em $\mathrm{mm}$ ), médias das temperaturas máxima $\left(\mathrm{em}^{\circ} \mathrm{C}\right)$, mínima e média, somatório da radiação solar global (em $\mathrm{MJ} / \mathrm{m}^{2}$ dia), média da umidade relativa do ar (em\%) e déficit e excesso hídrico do solo (em $\mathrm{mm}$ ), nos diferentes períodos (em dias) que antecedem à colheita do trigo EMBRAPA 16.

\begin{tabular}{|c|c|c|c|c|c|}
\hline Variável meteorológica & $\begin{array}{c}N^{\circ} \text { de } \\
\text { amostras }\end{array}$ & Média & $\begin{array}{c}\text { Valor } \\
\text { mínimo }\end{array}$ & $\begin{array}{l}\text { Valor } \\
\text { máximo }\end{array}$ & $\begin{array}{l}\text { Desvio } \\
\text { padrão }\end{array}$ \\
\hline \multicolumn{6}{|c|}{ Um a dez dias antes da colheita } \\
\hline Precipitação pluvial & 52 & 47,8 & 0,0 & 162,2 & 41,8 \\
\hline Temperatura máxima & 52 & 25,4 & 21,8 & 30,4 & 1,9 \\
\hline Temperatura mínima & 52 & 14,2 & 9,9 & 18,1 & 6,5 \\
\hline Temperatura média & 52 & 19,6 & 16,4 & 23,1 & 3,7 \\
\hline Radiação solar global & 23 & 179,4 & 86,5 & 257,7 & 43,8 \\
\hline Umidade relativa do ar & 52 & 72,1 & 52,7 & 86,9 & 7,6 \\
\hline Déficit hídrico do solo & 52 & 1,0 & 0,0 & 9,9 & 2,3 \\
\hline Excesso hídrico do solo & 52 & 33,0 & 0,0 & 157,3 & 40,78 \\
\hline \multicolumn{6}{|c|}{ Onze a vinte dias antes da colheita } \\
\hline Precipitação pluvial & 53 & 59,7 & 0,9 & 215,2 & 48,9 \\
\hline Temperatura máxima & 53 & 25,1 & 21,2 & 31,9 & 2,3 \\
\hline Temperatura mínima & 53 & 14,4 & 9,6 & 19,6 & 2,1 \\
\hline Temperatura média & 53 & 19,5 & 15,9 & 24,9 & 2,0 \\
\hline Radiação solar global & 24 & 166,1 & 88,2 & 219,9 & 38,8 \\
\hline Umidade relativa do ar & 52 & 75,7 & 52,2 & 90,2 & 8,1 \\
\hline Déficit hídrico do solo & 52 & 0,5 & 0,0 & 5,1 & 1,2 \\
\hline Excesso hídrico do solo & 52 & 36,2 & 0,0 & 196,2 & 45,5 \\
\hline \multicolumn{6}{|c|}{ Vinte e um a trinta dias antes da colheita } \\
\hline Precipitação pluvial & 52 & 56,3 & 0,0 & 244,2 & 50,9 \\
\hline Temperatura máxima & 52 & 24,1 & 20,0 & 28,9 & 2,4 \\
\hline Temperatura mínima & 52 & 13,6 & 9,5 & 19,3 & 2,2 \\
\hline Temperatura média & 52 & 18,8 & 15,4 & 23,8 & 1,9 \\
\hline Radiação solar global & 23 & 155,1 & 95,3 & 235,4 & 35,0 \\
\hline Umidade relativa do ar & 52 & 75,4 & 55,4 & 92,3 & 8,2 \\
\hline Déficit hídrico do solo & 51 & 0,6 & 0,0 & 8,3 & 1,7 \\
\hline Excesso hídrico do solo & 51 & 36,7 & 0,0 & 215,4 & 46,6 \\
\hline \multicolumn{6}{|c|}{ Trinta e um a quarenta dias antes da colheita } \\
\hline Precipitação pluvial & 53 & 74,5 & 4,4 & 231,3 & 59,8 \\
\hline Temperatura máxima & 53 & 23,1 & 17,1 & 28,9 & 2,2 \\
\hline Temp & 53 & 13,0 & 8,3 & 17,3 & 2,1 \\
\hline Temperatura média & 53 & 17,8 & 13,3 & 23,0 & 1,9 \\
\hline Radiaçã & 24 & 141,6 & 71,6 & 223,7 & 36,6 \\
\hline Umidade relativa do ar & 52 & 76,9 & 60,1 & 90,3 & 7,7 \\
\hline Déficit hídrico do solo & 52 & 0,5 & 0,0 & 10,2 & 1,8 \\
\hline Excesso hídrico do solo & 52 & 54,2 & 0,0 & 214,1 & 55,2 \\
\hline \multicolumn{6}{|c|}{ Quarenta e um a cinqüenta dias antes da colheita } \\
\hline Precipitação pluvial & 53 & 55,9 & 0,0 & 194,7 & 51,4 \\
\hline Temperatura máxima & 53 & 22,8 & 17,7 & 31,5 & 3,3 \\
\hline Temp & 53 & 12,5 & 6,4 & 16,8 & 2,5 \\
\hline Temperatu & 53 & 17,4 & 10,8 & 24,2 & 2,8 \\
\hline & 24 & 124,5 & 63,2 & 186,5 & 34,1 \\
\hline Umidade relativa do ar & 52 & 75,6 & 52,2 & 91,9 & 8,1 \\
\hline Déficit hídrico do solo & 52 & 1,1 & 0,0 & 15,8 & 3,2 \\
\hline Excesso hídrico do solo & 52 & 41,8 & 0,0 & 163,4 & 44,9 \\
\hline \multicolumn{6}{|c|}{ Cinqüenta e um a sessenta dias antes da colheita } \\
\hline Precipitação pluvial & 53 & 58,9 & 0,0 & 178,7 & 51,3 \\
\hline Temp & 53 & 21,6 & 9,3 & 31,0 & 3,5 \\
\hline & 53 & & 6,2 & & 2,7 \\
\hline Temperatura média & 53 & 16,3 & 9,6 & 25,1 & 2,8 \\
\hline Radiação solar global & 24 & 127,7 & 81,5 & 190,7 & 30,1 \\
\hline Umid & 52 & 75,5 & 49,1 & 89,6 & 8,4 \\
\hline Déficit hídrico do solo & 51 & 1,1 & 0,0 & 12,9 & 2,9 \\
\hline Excesso hídrico do solo & 51 & 48,2 & 0,0 & 203,3 & 61,4 \\
\hline \multicolumn{6}{|c|}{ Sesse nta e um a setenta dias antes da colheita } \\
\hline Prec & 53 & 50,3 & 0,0 & 281,3 & 58,5 \\
\hline Temp & 53 & 21,2 & 16,3 & 28,7 & 3,1 \\
\hline & 53 & 11,0 & 5,5 & 17,2 & 2,3 \\
\hline & & & 11,5 & 22,9 & 2,4 \\
\hline Radiação solar global & 23 & 127,4 & 76,5 & 192,9 & 34,5 \\
\hline Umidade relativa do ar & 51 & 76,4 & 49,9 & 94,4 & 10,2 \\
\hline Déficit hídrico do solo & 52 & 0,5 & 0,0 & & 1,4 \\
\hline Excesso hídrico do solo & 52 & 47,6 & 0,0 & 265,3 & 59,9 \\
\hline \multicolumn{6}{|c|}{ Setenta e um a oitenta dias antes da colheita } \\
\hline Precipitação pluvial & 53 & 55,7 & 0,0 & 239,9 & 54,0 \\
\hline & 53 & 21,1 & 8,6 & 29,3 & 3,5 \\
\hline Temp & 53 & 11,1 & 3,7 & 23,4 & 3,5 \\
\hline Tem & 53 & 16,1 & 7,1 & 23,3 & 3,1 \\
\hline ar global & 24 & 106,5 & 64,3 & 143,0 & 24,4 \\
\hline tiva do ar & 51 & 74,7 & 53,2 & 87,2 & 8,5 \\
\hline Déficit & 52 & 0,6 & 0,0 & 7,2 & 1,5 \\
\hline Excesso hídrico do solo & 52 & 32,7 & 0,0 & 165,7 & 40,4 \\
\hline
\end{tabular}

No entanto, dados obtidos neste trabalho estão em concordância com conclusões de NODA et al. [52], os quais determinaram que a quebra de dormência aumentou à medida que a temperatura de embebição foi elevada $\left(5,10,15\right.$ e $\left.20^{\circ} \mathrm{C}\right)$. Os resultados da Tabela 3 mostraram que a temperatura mínima média variou de 3,7 a $11,1^{\circ} \mathrm{C}$, nos periodos estudados.

O percentual de periodos em que a temperatura média associou-se negativamente com peso do hectolitro, peso de mil grãos e número de queda foi de 25,0\% e com rendimento de grãos, em $37,5 \%$ dos periodos. Para extração experimental de farinha e força geral de glúten, influência da temperatura média foi positiva em $50 \%$ dos períodos. Para relação $\mathrm{P} / \mathrm{L}$ e para microssedimentação com dodecil sulfato de sódio, a influência da temperatura média foi positiva em $12,5 \%$ e $37,5 \%$, respectivamente, e negativa em $25,0 \%$ e $12,5 \%$ dos periodos estudados, respectivamente (Figuras 1 a 8 ).

Neste trabalho, nos periodos estudados, a amplitude de variação da temperatura média foi de 7,1 a $25,1^{\circ} \mathrm{C}$, com médias variando de 16,1 a $19,6^{\circ} \mathrm{C}$ (Tabela 3). Considerando que temperatura superior a $15^{\circ} \mathrm{C}$ provoca decréscimo no peso do hectolitro e no rendimento de grãos, pode-se supor que a temperatura mais elevada, afetou negativamente essas características. A redução no rendimento de grãos ocasionada pela temperatura elevada resulta do efeito da temperatura na redução do período de enchimento de grãos, que não é compensado por aumento na taxa de crescimento dos grãos [68, 70].

Os resultados do presente trabalho estão em concordância com dados obtidos por STONE et al. [68] e por POPINEAU et al. [54], que mostram que temperatura mais baixa, quando os grãos estiverem imaturos, afeta negativamente a qualidade e a quantidade de glúten. Em temperatura mais elevada ocorre maior deposição de proteínas, comparativamente ao amido, com conseqüente aumento no teor de proteínas e de glúten nos grãos de trigo [68].

É possivel supor que a correlação negativa entre relação $\mathrm{P} / \mathrm{L}$ e média da temperatura média é devida à deposição diferencial das proteínas durante o período de enchimento de grãos [71]. O aumento da relação $\mathrm{P} / \mathrm{L}$ pode ser provocado pela elevação do teor de gluteninas, e a redução da relação P/L pode ser explicada pelo aumento do teor de gliadinas, como já comentado anteriormente.

A correlação negativa entre média da temperatura média e número de queda está em concordância com conclusões de NODA et al. [53], os quais determinaram que a quebra de dormência aumenta à medida que a temperatura de embebição é elevada (de 5 até $20^{\circ} \mathrm{C}$ ), diminuindo, conseqüentemente, o número de queda. Os resultados apresentados na Tabela 3 mostraram que a média da temperatura média variou de 16,1 a $19,6^{\circ} \mathrm{C}$, nos periodos estudados.

O percentual de periodos em que o somatório da radiação solar global associou-se positivamente com peso do hectolitro, peso de mil grãos, força geral de glúten e número de queda, foi de $62,5 \%$, com relação $\mathrm{P} / \mathrm{L}$ e rendimento de grãos foi de $50,0 \%$, e com extração experimental de farinha foi de $37,5 \%$. Somente microssedimentação 
com dodecil sulfato de sódio foi influenciada negativamente em $62,5 \%$ dos periodos estudados, pelo somatório da radiação solar global (Figuras 1 a 8).

A influência do somatório da radiação solar global no peso do hectolitro, no peso de mil grãos e no rendimento de grãos pode ser explicada pelas teorias sustentadas por vários autores [32, 34, 51, 54, 82, 83], os quais mostraram que a produção de grãos de trigo é proporcional à radiação fotossinteticamente ativa que é absorvida pelas plantas e que afeta os aportes de produtos fotossintéticos ao grão. Essa produção é determinada, em parte, pelo peso de grãos, que é influenciado pela duração e pela taxa de enchimento de grãos.

As correlações negativas entre somatório da radiação solar global e microssedimentação com dodecil sulfato de sódio, provavelmente, estão indicando que outro fator climático está influenciando essas correlações. Nos períodos estudados, a correlação entre somatório da radiação solar global e temperatura máxima média é de 0,94 . Isso mostra que, para fins de regressão, existe colinearidade entre essas duas características. Dessa forma, pode-se deduzir que a temperatura máxima média esteja afetando negativamente a microssedimentação com dodecil sulfato de sódio. Nesse sentido, autores como STONE \& NICOLAS [70] mostraram que temperatura moderadamente elevada influencia a qualidade da farinha, na percentagem de proteínas, ao alterar a taxa de acumulação das várias frações protéicas durante o enchimento de grãos.

As correlações positivas entre somatório da radiação solar global e número de queda obtidas neste trabalho contrariam resultados de STRAND [72], que mostrou que fotoperíodo longo (em que se observa maior incidência de radiação solar global), durante o desenvolvimento de grãos, associado a elevada temperatura e a baixa umidade, reduz o nivel de dormência em grãos maduros, aumentando a possibilidade de germinação na espiga e diminuindo o número de queda.

\section{4 - CONCLUSÕES}

O presente trabalho permitiu concluir, nas condições em que a cultivar EMBRAPA 16 foi avaliada e nos periodos estudados, que:

- a precipitação pluvial, a umidade relativa do ar e o excesso hídrico do solo influenciaram negativamente o peso do hectolitro, peso de mil grãos, número de queda, a relação $\mathrm{P} / \mathrm{L}$ e rendimento de grãos. A força geral de glúten, extração experimental de farinha e microssedimentação com dodecil sulfato de sódio foram afetadas, tanto positiva quanto negativamente, por essas variáveis, dependendo do período estudado;

- a temperatura minima influenciou positivamente a extração experimental de farinha, força geral e microssedimentação com dodecil sulfato de sódio. Para as demais variáveis, quando ocorreu influência da temperatura minima, esta foi negativa;
- a temperatura média associou-se negativamente com o peso do hectolitro, peso de mil grãos, número de queda e rendimento de grãos, e positivamente com extração experimental de farinha e força geral de glúten. Para a relação P/L e para microssedimentação com dodecil sulfato de sódio, a temperatura média afetou tanto positiva quanto negativamente;

- a temperatura máxima correlacionou-se negativamente com rendimento de grãos, e positivamente com extração experimental de farinha. A força geral de glúten, microssedimentação com dodecil sulfato de sódio e relação P/L apresentaram períodos de correlação positivos e negativos com a temperatura máxima;

- a radiação solar global influenciou positivamente todas as características estudadas, exceto microssedimentação com dodecil sulfato de sódio.

\section{5 - REFERÊNCIAS BIBLIOGRÁFICAS}

[1] AMERICAN ASSOCIATION OF CEREAL CHEMISTS. Approved methods of the AACC, St. Paul, Minnesota, 1983.

[2] AMORIM, H. V. Respiração. In: FERRI, M.G. coord. Fisiologia vegetal. São Paulo: Editora Pedagógica e Universitária Ltda., v. 1 Cap. 6: p. 251-279, 1985.

[3] AXFORD, D.W.E.; McDERMOTT, E.E.; REDMAN, D.G. Smallscale tests of bread-making quality. Milling Feed and Fertilizer, Herts, v. 161, n. 1, p. 18-20, Jan., 1978.

[4] BALANÇAS DALLE MOLLE (Caxias do Sul). Instruções para montagem da balança de peso específico. Caxias do Sul, [19- -].

[5] BERGAMASCHI, H. Desenvolvimento de déficit hídrico em culturas. In: BERGAMASCHI, H. Coord. Agrometeorologia aplicada à irrigação. Porto Alegre: Editora da Universidade/UFRGS, cap. 1:p. 25-32, 1992.

[6] BHATT, G.M.; PAUlSEn, G.M.; KUlP, K; HeYNe, E.G. Preharvest spouting in hard winter wheats assessment of methods to detect genotypic and nitrogen effects and interactions. Cereal Chemistry, St.Paul, v. 58, n. 4, p. 300-302, Jul., 1981.

[7] BHULLAR, S.S.; JENNER, C.F. Effects of temperature on the conversion of sucrose to starch in the developing wheat endosperm. Australian Journal of Plant Physiology, Melbourne, v. 13, n. 5, p. 605-615, Mar., 1986.

[8]BLACK, M.; BUTLER, J.; HUGHES, M. Control and development of dormancy en cereals . In: RINGLUND, K.; MOSLETH, E.; MARES, D. J. (eds.). Fourth International Symposium on Pre-harvest (Sprouting in Cereals, Westview Press, Colorado, 1987, p. 13-15.

[9] BLUMENTHAL, C.; BEKES, F.; GRAS, P. W.; BARLOW, E.W.R.; WRIGLEY, C.W. Identification of wheat genotypes tolerant to the effects of heat stress on grain quality. Cereal Chemistry, St.Paul, v. 72, n. 6, p. 539-544, Nov., 1995.

[10] BLUMENTHAL, C.S.; BATEY, I.L.;BEKES, F.; WRIGLEY, C.W.; BARLOW, E.W.R. Seasonal changes in wheat grain quality associated with high temperature. Australian Journal of Agricultural Research, Melbourne, v. 42, n. 1, p. 21-30, Jan., 1991a.

[11] BLUMENTHAL, C.S.; BEKES, F.; BATEY, I.L.; WRIGLEY, C.W.; MOSS, H.J.; MARES, D.J.; BARLOW, E.W.R. Interpretation of grain quality 
results from wheat variety trials with reference to high temperature stress. Australian Journal of Agricultural Research, Melbourne, v. 42, n. 3, p. 325-334, May, 1991b.

[12] BRASIL. Ministério da Agricultura e Reforma Agrária. Secretaria Nacional de Defesa Agropecuária. Regras de análises para sementes. Brasília, p. 194-195, 1992.

[13] CHOWDHURY, S.Y.; WARDLAW, I.F. The effect of temperature on kernel development in cereal. Australian Journal of Agricultural Research, Melbourne, v. 29, n. 2, p. 205-225, Mar., 1978.

[14] CIAFFI, M.; TOZZI, L.; BORGHI, B.; CORBELLINI, M.; LAFIANDRA, D. Effect of heat shock during grain filling on the gluten protein composition of bread wheat. Journal of Cereal Science, London, v. 24, n. 2, p. 91100, Sept., 1996.

[15] CLASSEN, M.M.; SHAW, R.H. Water deficit effects on corn. I. Vegetative components. Agronomy Journal, Madison, v. 62, n. 5, p. 649-652, Oct., 1970.

[16] CORNFORD, C.A.; BLACK, M.; CHAPMAN, J. Sensitivity of developing wheat grains to gibberellin and production of alfa-amylase during grain development and maturation. In: RINGLUND, K.; MOSLETH, E.; MARES, D.J., (Eds.), Fourth International Symposium on Preharvest Sprouting in Cereals, Westview Press, Colorado, p. 283-292, 1987.

[17] CUNHA, G.R. Meteorologia: fatos \& mitos. Passo Fundo: EMBRAPA-CNPT, 268p., 1997.

[18] CUNHA, G.R.; HAAS, J.C.; ASSAD, E.D. Zoneamento de riscos climáticos para a cultura de trigo no Rio Grande do Sul. Pesquisa Agropecuária Gaúcha, Porto Alegre, v. 5, n. 1, p. 55-62, 1999.

[19] DÁVAlos, E.D.; PACHECO, A.C.; HENNIGEN, J. Avaliação de cultivares de Trigo em Santa Catarina - 1998. Chapecó: EPAGRI - Centro de Pesquisa para Pequenas Propriedades, 1999. 15p. Trabalho apresentado na XXXI Reunião da Comissão Sul-Brasileira de Pesquisa de Trigo, Passo Fundo, 1999.

[20] DÁVALOS, E.D.; PACHECO, A.C.; HENNIGEN, J.; MACHADO, E.O. Avaliação de cultivares de trigo em Santa Catarina - 1991. In: REUNIÃO DA COMISSÃO SUL-BRASILEIRA DE PESQUISA DE TRIGO, 24., 1992, Cruz Alta. Ata... Cruz Alta: FUNDACEP - FECOTRIGO - Fundação Centro de Experimentação e Pesquisas - FECOTRIGO, p. 22, 1992.

[21] DÁVALOS, E.D.; PACHECO, A.C.; HENNIGEN, J.; MACHADO, E.O. Avaliação de cultivares de trigo em Santa Catarina - 1993. Chapecó: EPAGRI - Centro de Pesquisa para Pequenas Propriedades, 1994. 13p. Trabalho apresentado na XXVI Reunião da Comissão Sul-Brasileira de Pesquisa de Trigo, Chapecó, 1994.

[22] DÁVALOS, E.D.; PACHECO, A.C.; HENNIGEN, J.; MACHADO, E.O. Avaliação de cultivares de trigo em Santa Catarina - 1994. Chapecó: EPAGRI - Centro de Pesquisa para Pequenas Propriedades, $17 \mathrm{p}$. Trabalho apresentado na XXVII Reunião da Comissão Sul-Brasileira de Pesquisa de Trigo, Porto Alegre, 1995.

[23] DÁVALOS, E.D.; PACHECO, A.C.; HENNIGEN, J.; MACHADO, E.O. Avaliação de cultivares de trigo em Santa Catarina - 1995. Chapecó: EPAGRI - Centro de Pesquisa para Pequenas Propriedades, 19p. Trabalho apresentado na XXVIII Reunião da Comissão Sul-Brasileira de Pesquisa de Trigo, Passo Fundo, 1996.

[24] DÁVAlos, E.D.; PACHECO, A.C.; HENNIGEN, J.; MACHADO, E.O. Avaliação de cultivares de trigo em
Santa Catarina - 1996. Chapecó: EPAGRI - Centro de Pesquisa para Pequenas Propriedades, 20p. Trabalho apresentado na XXIX Reunião da Comissão SulBrasileira de Pesquisa de Trigo, Porto Alegre, 1997.

[25] DÁVAlos, E.D.; PACHECO, A.C.; HENNIGEN, J.; MACHADO, E.O. Avaliação de cultivares de trigo em Santa Catarina - 1997. Chapecó: EPAGRI - Centro de Pesquisa para Pequenas Propriedades, $17 \mathrm{p}$. Trabalho apresentado na XXX Reunião da Comissão SulBrasileira de Pesquisa de Trigo, Chapecó, 1998.

[26] DEL DUCA, L.J.A.; SOUSA, C.N. A. DE; GOMES, E.P.; GUARIENTI, E.M.; MOREIRA, J.C.S.; SARTORI, J.F.; MEDEIROS, M.; SCHEEREN, P. L. Descrição e desempenho da cultivar de trigo Embrapa 16, recomendada para o Rio Grande do Sul e para Santa Catarina. Passo Fundo: CNPT - Centro Nacional de Pesquisa de Trigo, p. 121. Trabalho apresentado na XVII Reunião Nacional de Pesquisa de Trigo, Passo Fundo, 1994.

[27] DEXTER, J.E.; MARTIN, D.G.; PRESTON, K.R.; TIPPLES, K.H.; MacGREGOR, A.W. The effect of frost damage on the milling and baking quality of red spring wheat. Cereal Chemistry, St.Paul, v. 62, n. 2, p. 75-80, Mar., 1985.

[28] DUBETZ, S.; BOLE, J.B. Effects of moisture stress at early heading and of nitrogen fertilizer on three spring wheat cultivars. Canadian Journal of Plant Science, Ottawa, v. 53, n. 1, p. 1-5, Jan. , 1973.

[29] FERRÃO,M.F. Aplicação de técnicas espectroscópicas de reflexão no infravermelho no controle de qualidade de farinha de trigo. Campinas, 217p. Tese (Doutor em Química) - Instituto de Química, Universidade Estadual de Campinas. 2000.

[30 FINNEY, K.; YAMAZAKI, W. Quality of hard, soft and durum wheats. In: QUINSENBERRY, K.S.; REITZ, L.P. , ed. Wheat and wheat improvement. Madison: American Society of Agronomy, Chap. 14, p. 471-503. (Agronomy, 13), 1967.

[31] FINNEY, K.F.; FRYER, H.C. Effects on loaf volume of high temperatures during the fruiting period of wheat. Agronomy Journal, Madison, v. 50, n. 1, p. 28-34, Jan., 1958.

[32] FORD, M.A.; PEARMAN, I.; THORNE, G.N. Effects of variation in ear temperature on growth and yield of spring wheat. Annals of Applied Biology, Warwick, v. 82. n. 2, p. 317-333, Mar., 1976.

[33] GONÇALVES, S.L.; CARAMORI, P. H.; WREGE, M.S.; BRUNETTA, D.; DOTTO, S.R. Regionalização para épocas de semeadura de trigo no estado do Paraná. Revista Brasileira de Agrometeorologia, Santa Maria, v. 6, n. 2, p. 239-248, 1998.

[34] GRABAU, L.J.; VAN SANFORD, D.A.; MENG, Q.W Reproductive characters of winter wheat cultivars subjected to postanthesis shading. Crop Science, Madison, v. 20, n. 4, p. 771-774, Jul./August, 1990.

[35] GRAYBOSCH, R.A.; MORRIS, R. An improved SDSPAGE method for the analysis of wheat endosperm storage proteins. Journal of Cereal Science, London, v. 11, n. 3, p. 201-212, May, 1990.

[36] GRAYBOSCH, R.A.; PETERSON, C.J.; BAENZIGER, P. S.; SHELTON, D.R. Environmental modification of hard red winter wheat flour protein composition. Journal of Cereal Science, London, v. 22, n. 1, p. 45-51, Jul., 1995.

[37] GUARIENTI, E.M. Qualidade industrial de trigo. Passo Fundo: EMBRAPA-CNPT, 36p., 1996. (EMBRAPACNPT. Documentos, 27). 
[38] HIRANO, J. Effects of rain in ripening period on the grain quality of wheat. Japan Agricultural Research Quarterly, Ibaraki, v. 10, n. 4, p. 168-173, Oct., 1976.

[39] JOHNSON, J.A.; KHAN, M.N. ; SANCHEZ, C.R.S.; Wheat cultivars, environment and bread-baking quality. Cereal Science Today, St. Paul, v. 17, n. 10, p. 323326, Oct., 1972.

[40] KOLDERUP, F. Effects of temperature, photoperiod, and light quantity on yield capacity of wheat. Meldinger fra Norges Landbrukshegskole, v. 53 , n. 36 , p. 1$10,1974$.

[41] MANDARINO, J.M.G. Componentes do trigo: características físico-químicas, funcionais e tecnológicas. Londrina: EMBRAPA-CNPSo, 36p., 1994. (EMBRAPACNPSo. Documentos, 75).

[42] MANGELS, C.E. Pre-harvest factors which affect wheat quality. Cereal Chemistry, St. Paul, v. 4, n. 5, p. 376388, Sept., 1927.

[43] MELLADO Z., M.; MALDONADO I., I.; GRANGER Z.,D. Efecto de la lluvia, posterior a la madurez de cosecha, sobre el grano de trigo. Agricultura Tecnica, Santiago, v. 45, n. 3, p. 247-251, Jul./Septiembre, 1985.

[44] MOREIRA, J.C.S. Resultados dos Ensaios Sul-Brasileiros de Trigo no Rio Grande do Sul, em 1990. Passo Fundo: EMBRAPA -CNPT, Centro Nacional de Pesquisa de Trigo, 19p. Trabalho apresentado na XXIII Reunião da Comissão Sul-Brasileira de Pesquisa de Trigo, Pelotas, 1991.

[45] MOREIRA, J.C.S. Resultados dos Ensaios Sul-Brasileiros de Trigo no Rio Grande do Sul, em 1996. Passo Fundo, EMBRAPA - CNPT, 25p. (EMBRAPA-CNPT. Documentos, 32). Trabalho apresentado na XXIX Reunião da Comissão Sul-Brasileira de Pesquisa de Trigo, Porto Alegre, 1997.

[46] MOREIRA, J.C.S. Resultados dos Ensaios Sul-Brasileiros de Trigo no Rio Grande do Sul, em 1995. Passo Fundo, EMBRAPA - CNPT, 27p. (EMBRAPA-CNPT. Documentos, 25). Trabalho apresentado na XXVIII Reunião da Comissão Sul-Brasileira de Pesquisa de Trigo, Passo Fundo, 1996.

[47] MOREIRA, J.C.S. Resultados dos Ensaios Sul-Brasileiros de Trigo no Rio Grande do Sul, em 1991. Passo Fundo, EMBRAPA - CNPT, 24p. (EMBRAPA-CNPT. Documentos, 1). Trabalho apresentado na XXIV Reunião da Comissão Sul-Brasileira de Pesquisa de Trigo, Cruz Alta, 1992.

[48] MOREIRA, J.C.S. Resultados dos Ensaios Sul-Brasileiros de Trigo no Rio Grande do Sul, em 1994. Passo Fundo, EMBRAPA - CNPT, 1995. 28p. (EMBRAPA-CNPT. Documentos, 20). Trabalho apresentado na XXVII Reunião da Comissão Sul-Brasileira de Pesquisa de Trigo, Porto Alegre, 1995.

[49] MOSS, H.J.; DERERA, N. F.; BALAAM, L.N. Effect of preharvest rain on germination in the ear and a-amylase activity of Australian wheat. Australian Journal of Agricultural Research, Melbourne, v. 23, n. 5, p. 769777, Sept., 1972.

[50] MOTA, F.S. Clima e zoneamento para a triticultura no Brasil. Pelotas: UFPel, 1980. 32p. (UFPel. Boletim Técnico, 3).

[51] MOU, B.; KRONSTAD, W.E.; SAULESKU, N. N. Grain filling parameters and protein content in selected winter wheat population: II. Associations. Crop Science, Madison, v. 34, n. 4, p. 838-841, Jul./August, 1994.

[52] NODA, K.; KAWABATA, C.; KAWAKAMI, N. Response of wheat grain to $\mathrm{ABA}$ and imbibition at low temperature. Plant Breeding, Berlin, v. 113, n. 1, p. 53-57, Aug., 1994.
[53] POPINEAU, Y.; CORNEC, M.; LEFEBVRE, J.; MARCHYLO, B. Influence of high $\mathrm{Mr}$ glutenin subunits on glutenin polymers and rheological properties of glutens and gluten subfraction of near-isogenic lines of wheat Sicco. Journal of Cereal Science, New York, v. 19, p. 231241, Nov. , 1993.

[54] POZO L., A. del. El rol de la temperatura y radiacion solar en el crecimiento y la producción del trigo primaveral, com diferentes epocas de siembra. Agricultura Tecnica, Santiago, v. 48, n. 3, p. 242-251, Jul./Septiembre, 1988.

[55] PRESTON, K.R.; KILBORN, R.H.; MORGAN, B.C.; BABB, J.C. Effects of frost and immaturity on the quality of a Canadian hard red spring wheat. Cereal Chemistry, St.Paul, v. 68, n. 2, p. 133-138, Mar., 1991.

[56] PUZZI, D. Padronização de cereais, grãos leguminosos e café. In: PUZZI, D. Abastecimento e armazenagem de grãos. Campinas: Instituto Campineiro de Ensino Agrícola, 1986. Cap. 22: p. 573-580.

[57] RAO, A.C.S.; SMITH, J.L.; JANDHYALA, V.K.; PAPENDICK, R.I.; PARR, J.F. Cultivar and climatic effects on the protein content of soft white winter wheat. Agronomy Journal, Madison, v. 85, n. 5, p. 1023-1028, Sept./ October, 1993.

[58] READ, D.W.L.; WARDER, F.G. Influence of soil and climatic factors on fertilizer response of wheat grown on stubble land in southwestern Saskatchewan. Agronomy Journal, Madison, v. 66, n. 2, p. 245248, Mar./April, 1974.

[59] REICHARDT, K. A água: absorção e translocação. In: FERRI, M.G. coord. Fisiologia vegetal. São Paulo: Editora Pedagógica e Universitária Ltda., v. 1 Cap. 1: p. 3-24, 1985.

[60] RODRIGUES, O. Manejo de trigo: bases ecofisiológicas. In: CUNHA, G.R.; BACALTCHUK, B. Orgs. Tecnologia para produzir trigo no Rio Grande do Sul. Porto Alegre: Assembléia Legislativa. Comissão de Agricultura, Pecuária e Cooperativismo/Passo Fundo: Embrapa Trigo, 2000. Cap. 8:p. 120-155. (Série Culturas, n. 02).

[61] ROlim, G.S.; SENTElhas, P. C.; BARBIERI, V. Planilhas no ambiente Excel ${ }^{\mathrm{TM}}$ para os cálculos de balanços hídricos: normal, seqüencial, de cultura e de produtividade real e potencial. Revista Brasileira de Agrometeorologia, Santa Maria, v. 6, n. 1, p. 133137, Jan. , 1998.

[62] SCHIPPER, A. Modifications of the dough physical properties of various wheat cultivars by environmental influences. Agribiology Research, v. 44, n. 1, p. 114-132, 1991.

[63] SHEPHERD, K.W. Genetics of wheat endosperm proteins - in retrospect and prospect. In: INTERNATIONAL WHEAT GENETICS SYMPOSIUM, 7., 1988, Cambridge. Proceedings. Cambridge: Institute of Plant Science Research, 1988. v. 2, p. 919-931.

[64] SMIKA, D.E.; GREB, B. W. Protein content of winter wheat grain as related to soil and climatic factors in the semiarid central great plains. Agronomy Journal, Madison, v. 65, n. 3, p. 433-436, May/June, 1973.

[65] SOCIEDADE BRASILEIRA DE CIÊNCIA DO SOLO. Comissão de Fertilidade do Solo-RS/SC. Recomendação de adubação e de calagem para os estados do Rio Grande do Sul e de Santa Catarina. 3ed. Passo Fundo, 1995. 223p.

[66] SPIERTZ, J.H.J. The influence of temperature and light intensity on grain growth in relation to carbohydrate 
and nitrogen economy on wheat plant. Netherlands Journal of Agricultural Science, Wageningen, v. 25, n. 3, p. 182-197, Mar., 1977.

[67] STONE, P. J.; GRAS, P. W.; NICOLAS, M.E. The influence of recovery temperature on the effects of a brief heat shock on wheat. III. Grain protein composition and dough properties. Journal of Cereal Science, London, v. 25, n. 1, p. 129-141, Jul., 1997.

[68] STONE, P. J.; NICOLAS, M.E. A survey of the effects of high temperatures during grain filling on yield and quality of 75 wheat cultivars. Australian Journal of Agricultural Research, Melbourne, v. 46, n. 3, p. 475-492, May, 1995a.

[69] STONE, P. J.; NICOLAS, M.E. Comparison of sudden heat stress with gradual exposure to high temperature during grain filling in two wheat varieties differing in heat tolerance. I. Grain growth. Australian Journal of Plant Physiology, Melbourne, v. 22, n. 6, p. 935-944, Dec., 1995b.

[70] STONE, P. J.; NICOLAS, M.E. Effect of timing of heat stress during grain filling on two wheat varieties differing in heat tolerance. II. Fractional protein accumulation. Australian Journal of Plant Physiology, Melbourne, v. 23, n. 6, p. 739-749, Dec., 1996.

[71] STONE, P. J.; NICOLAS, M.E. Wheat cultivars vary widely in their responses of grain yield and quality to short periods of post-anthesis heat stress. Australian Journal of Plant Physiology, Melbourne, v. 21, n. 6, p. 887-900, Dec., 1994.

[72] STRAND, E. Studies on seed dormancy in small grain species. The Journal of Agricultural Science, London, v. 3, n. 1, p. 85-99, Feb., 1989.

[73] SVOBODA, L.H.; TONON, V.D.; NETO, N. ; MATZENBACHER, R.G. Resultados do Ensaio Regional de Linhagens de Trigo no Rio Grande do Sul, em 1996. Cruz Alta: FUNDACEP - Fundação Centro de Experimentação e Pesquisa FECOTRIGO, 1997. 17p. Trabalho apresentado na XXIX Reunião da Comissão SulBrasileira de Pesquisa de Trigo, Porto Alegre, 1997.

[74] SVOBODA, L.H.; TONON, V.D.; NETO, N. ; MATZENBACHER, R.G. Resultados do Ensaio Regional de Linhagens de Trigo no Rio Grande do Sul, em 1994. Cruz Alta: FUNDACEP - Fundação Centro de Experimentação e Pesquisa FECOTRIGO, 1995. 25p. Trabalho apresentado na XXVII Reunião da Comissão SulBrasileira de Pesquisa de Trigo, Porto Alegre, 1995.

[75] THOMÉ, V.M.R.; ZAMPIERI, S.L.; BRAGA, H.J. Zoneamento para a cultura do trigo em Santa Catarina. Florianópolis: EPAGRI, 1996. 24p. (EPAGRI, Documentos, 17).

[76] THORNTHWAITE, C.; MATHER, R.J. The water balance. New Jersey: Laboratory of Climatology, 1955. V.8, 104p. (Publication in Climatology).

[77] UHLEN, A.K.; HAFSKJOLD, R. KALHOVD, A.H.; SAHLSTRÖM, S.; LONGUA, A; MAGNUS, E.M. Effects of cultivar and temperature during grain filling on wheat protein content, composition, and dough mixing properties. Cereal Chemistry, St. Paul, v. 75, n. 4, p. 460-465, Jul./August, 1998.

[78] WALDMAN, L.; CAUMO, A. Resultados do Ensaio Estadual de Cultivares de Trigo no Rio Grande do Sul, em 1994. Porto Alegre: FEPAGRO - Fundação Estadual de Pesquisa Agropecuária, 1995. 22p. Trabalho apresentado na XVII Reunião da Comissão SulBrasileira de Pesquisa de Trigo, Porto Alegre, 1995.

[79] WALDMAN, L.; CAUMO, A.; MAIRESSE, L.A.S.; ZANOTELLI, V. Resultados do Ensaio Estadual de Cultivares de Trigo no Rio Grande do Sul, em 1993. Porto Alegre: IPAGRO-CIENTEC - Instituto de Pesquisas Agronômicas, 1994. 24p. Trabalho apresentado na XIV Reunião da Comissão Sul-Brasileira de Pesquisa de Trigo, Chapecó, 1994.

[80] WARDLAW, I.F.; DAWSON, I.A.; MUNIB, P. The tolerance of wheat to high temperatures during reproductive growth. II. Grain development. Australian Journal of Agricultural Research, Melbourne, v. 40, n. 1, p. 15-24, Jan. , 1989.

[81] WARDLAW, I.F.; SOFIELD, I.; CARTWRIGHT, P. M. Factors limiting the rate of dry matter accumulation in the grain of wheat grown at high temperature. Australian Journal of Plant Physiology, Melbourne, v. 7, n. 4, p. 387-400, Aug., 1980.

[82] WARDLAW, I.F. The early stages of grain development in wheat: response to light and temperatura in a single variety. Australian Journal of Biology Science. Melbourne, v. 23, n. 6, p. 765-774, Dec., 1971.

[83] WIEGAND, C.L.; CUELLAR, J.A. Duration of grain filling and kernel weight as affected by temperature. Crop Scince, Madison, n. 21, n. 1, p. 95-101, Jan./ February, 1981.

[84] ZANOTELli, V.; LOSSO, A.C.; BERTOLDO, N. ; TOMAZZI, D.; BELTRÃO, L. CAETANO, W. Ensaio Estadual de Cultivares de Trigo no Rio Grande do Sul, em 1998. Porto Alegre: FEPAGRO - Fundação Estadual de Pesquisa Agropecuária, 1999. 18p. Trabalho apresentado na XXXI Reunião da Comissão SulBrasileira de Pesquisa de Trigo, Passo Fundo, 1999.

[85] ZANOTELLI, V.; LOSSO, A.C.; BERTOLDO, N. ; TOMAZZI, D.; BELTRÃO, L. CAETANO, W. Ensaio Estadual de Cultivares de Trigo - RS - 1992. Porto Alegre: IPAGRO- CIENTEC - Instituto de Pesquisas Agronômicas, 1993. 23p. Trabalho apresentado na XXV Reunião da Comissão Sul-Brasileira de Pesquisa de Trigo, Passo Fundo, 1993.

[86] ZANOTELli, V.; LOSSO, A.C.; BERTOLDO, N. ; TOMAZZI, D.; BELTRÃO, L. CAETANO, W. Ensaio Estadual de Cultivares de Trigo no Rio Grande do Sul, em 1997. Porto Alegre: FEPAGRO - Fundação Estadual de Pesquisa Agropecuária, 1998. 20p. Trabalho apresentado na XXX Reunião da Comissão SulBrasileira de Pesquisa de Trigo, Chapecó, 1998. 